\title{
Article \\ Effect of Vanadium and Strain Rate on Hot Ductility of Low-Carbon Microalloyed Steels
}

\author{
Siying Song ${ }^{1}$, Junyu Tian ${ }^{1, *}$, Juan Xiao ${ }^{2}$, Lei Fan ${ }^{2}$, Yuebiao Yang ${ }^{2}$, Qinpan Yuan ${ }^{2}$, Xiaolong Gan ${ }^{1}$ \\ and Guang $X \mathbf{u}^{1, * \mathbb{D}}$
}

1 Hubei Collaborative Innovation Center for Advanced Steels, The State Key Laboratory of Refractories and Metallurgy, Wuhan University of Science and Technology, Wuhan 430081, China; songsiying2206@gmail.com (S.S.); Ganxiaolong@wust.edu.cn (X.G.)

2 Guangxi Liuzhou Iron and Steel Group Co., Ltd., Liuzhou 545002, China; bunana677@gmail.com (J.X.); fl13788221681@gmail.com (L.F.); yangyuebiao@gmail.com (Y.Y.); yqp13659666344@gmail.com (Q.Y.)

* Correspondence: tianjunyu@wust.edu.cn (J.T.); xuguang@wust.edu.cn (G.X.); Tel.: +86-131-6417-8028 (J.T.); +86-156-7198-0996 (G.X.)

check for updates

Citation: Song, S.; Tian, J.; Xiao, J.; Fan, L.; Yang, Y.; Yuan, Q.; Gan, X.; $\mathrm{Xu}, \mathrm{G}$. Effect of Vanadium and Strain Rate on Hot Ductility of Low-Carbon Microalloyed Steels. Metals 2022, 12, 14. https://doi.org/10.3390/ met12010014

Academic Editor: Alexander Ivanovich Zaitsev

Received: 18 November 2021 Accepted: 16 December 2021 Published: 22 December 2021

Publisher's Note: MDPI stays neutral with regard to jurisdictional claims in published maps and institutional affiliations.

Copyright: (C) 2021 by the authors. Licensee MDPI, Basel, Switzerland. This article is an open access article distributed under the terms and conditions of the Creative Commons Attribution (CC BY) license (https:// creativecommons.org/licenses/by/ $4.0 /)$.

\begin{abstract}
Hot tensile tests were conducted in this study to investigate the effect of strain rate $\left(10^{-3}\right.$ and $\left.10 \mathrm{~s}^{-1}\right)$ and vanadium content $(0.029$ and $0.047 \mathrm{wt} . \%)$ on the hot ductility of low-carbon microalloyed steels. The results indicate that a hot ductility trough appears at a low strain rate $\left(10^{-3} \mathrm{~s}^{-1}\right)$ because of the sufficient time for ferrite transformation and the growth of second particles, but it disappears at a high strain rate $\left(10 \mathrm{~s}^{-1}\right)$. The hot ductility is improved with the increase in strain rate at $700{ }^{\circ} \mathrm{C}$ or higher temperatures. In addition, with the increase in vanadium content, the large amounts of precipitate and increased ferrite transformation result in poor hot ductility of steels fractured at a low temperature range $\left(600 \sim 900^{\circ} \mathrm{C}\right)$. However, when the steel is fractured at a high temperature range $\left(1000 \sim 1200^{\circ} \mathrm{C}\right)$, more vanadium in the solid solution in the austenite inhibits the growth of parental austenite grains and results in grain refinement strengthening, slightly improving the hot ductility.
\end{abstract}

Keywords: hot ductility; strain rate; vanadium; ferrite transformation; precipitate

\section{Introduction}

Recently, microalloyed steels with superior mechanical properties have received much attention due to how the reheating treatment after part formation can be cut out from the entire production process, thus saving significant costs and energy. However, during the straightening operation of steel produced by a continuous casting process, transverse cracks must be considered as this is a serious problem in microalloyed steels [1-3]. The research on hot ductility behaviors of steels is significant in determining the straightening temperature. Usually, in the straightening operation, the steels exhibit a minimum ductility in laboratory hot tensile tests [4]; thus, the simple hot tensile test has proven very useful in assessing the likelihood of cracking in steels.

Microalloying elements, niobium $(\mathrm{Nb})$, vanadium $(\mathrm{V})$ and titanium $(\mathrm{Ti})$, are playing an important role in grain refinement and precipitation strengthening in microalloyed steels, and they also impact the hot ductility of steels. Compared to $\mathrm{Nb}$ and $\mathrm{Ti}, \mathrm{V}$ is more commonly added to high-strength steels to ensure considerable grain refinement strengthening and precipitation strengthening because of its higher solubility and lower precipitation temperature compared to $\mathrm{Ti}$ and $\mathrm{Nb}$. However, the temperature of the precipitation of $\mathrm{V}$-containing precipitates crosses the range of straightening temperature in the industrial production process, meanwhile, the addition of $\mathrm{V}$ can also affect the transformation process of steels; therefore, it is necessary to study the effect of $\mathrm{V}$ on hot ductility in microalloyed steels for designing better straightening operation parameters. Mintz et al. [4] investigated the effect of $\mathrm{V}$ and $\mathrm{Nb}$ on the hot ductility of steels. The results indicated that $\mathrm{V}$-containing steels exhibited higher hot ductility than $\mathrm{Nb}$-containing steel due to the higher solubility of $\mathrm{V}(\mathrm{C}, \mathrm{N})$ in austenite; however, increasing the $\mathrm{V}$ content 
caused deeper and wider low ductility troughs. Similarly, the hot ductility behavior of four plain carbon steels containing different $\mathrm{V}$ contents has been investigated by Mohamed [5]; this revealed that raising the $\mathrm{V}$ content from 0.009 to $0.1 \%$ was found to deteriorate the ductility because the ductility trough became wider and deeper as the $\mathrm{V}$ content increased due to the increased amount of VN precipitate in the steel. In addition, Lee et al. [6] studied the hot ductility of a medium-carbon steel that contained $\mathrm{V}$ and demonstrated that $\mathrm{V}(\mathrm{C}, \mathrm{N})$ particles precipitated at the austenite grain boundary and deteriorated the hot ductility when in a temperature range of $800 \sim 950{ }^{\circ} \mathrm{C}$. Research on Ti- and V-bearing microalloyed steels by Sun et al. [7] also demonstrated that the precipitate, especially with the size of 10 30 nm, resulted in a sharp decrease in hot ductility. However, SalasReyes [8] reported that the reduction in area (RA) of the V-microalloyed TWIP steel showed a significant improvement $\left(800 \sim 900{ }^{\circ} \mathrm{C}\right)$ due to the fine VC particles, which promotes dynamic recrystallization. Similarly, Irvine and Pickering [9] claimed that V might improve ductility because its addition was found to hinder AlN precipitation. As mentioned above, it is easy to know that the effect of $\mathrm{V}$ on hot ductility is crucial and is still debatable at present; therefore, it is of great significance to study the influence of $\mathrm{V}$ on the hot ductility of low-carbon microalloyed steels.

In addition, the hot ductility of steels is also influenced by strain rate. For example, Zheng et al. [10] studied the effect of strain rate from 0.005 to $0.5 \mathrm{~s}^{-1}$ on the hot ductility of a Cr-Mo steel, indicating that increasing the strain rate improved the hot ductility because the formation of ferrite was promoted at a higher strain rate but with no sufficient time to grow up. Similarly, the hot ductility of an $18 \mathrm{Mn} 18 \mathrm{Cr} 0.6 \mathrm{~N}$ steel at the strain rate range of 0.001 to $10 \mathrm{~s}^{-1}$ was investigated by Wang et al. [11], showing that a higher strain rate was beneficial for grain refinement and preventing hot cracking, which led to improved hot ductility. Regarding the microalloyed steels, Crowther et al. [12] analyzed the hot ductility of microalloyed steels with different strain rates between $3 \times 10^{-2} \mathrm{~s}^{-1}$ and $3 \times 10^{-4} \mathrm{~s}^{-1}$. The results showed that the best hot ductility was obtained at the highest strain rate of $3 \times 10^{-2} \mathrm{~s}^{-1}$, and the deterioration of hot ductility at lower strain rates was caused by retarding the onset of dynamic recrystallization by grain boundary precipitates. In addition, the influence of strain rate on the hot ductility of a V-containing steel slab was investigated by Großeiber et al. [13] at strain rates of $3 \times 10^{-4} \mathrm{~s}^{-1}$ to $0.3 \mathrm{~s}^{-1}$. They claimed that the hot ductility improved with the increase in strain rate and the fracture mode changed from intergranular to transgranular. Imperfectly, the testing temperatures in their study only ranged from 700 to $850{ }^{\circ} \mathrm{C}$.

Summarizing the aforementioned results, much research has investigated the hot ductility of steels at different testing temperatures and strain rates. However, to the authors' knowledge, few investigations have been conducted in the field of V-microalloyed lowcarbon steels with a wider range of strain rates. Therefore, in the present study, the effects of $\mathrm{V}$ content and strain rate at a wider strain rate range on the hot ductility and fracture mechanism of V-microalloyed steels were investigated, aiming to provide a theoretical reference for optimizing the parameters of the practical industrial production process.

\section{Materials and Methods}

Two low-carbon microalloyed steels with V contents of 0.029 and 0.041 wt.\% were used, named as VL and VH, respectively. The tested steels were produced by Liuzhou Iron \& Steel Co., Ltd. Their chemical compositions are shown in Table 1.

Table 1. The chemical composition of two tested steels.

\begin{tabular}{cccccccc}
\hline Steels & Fe & $\mathbf{C}$ & $\mathbf{S i}$ & $\mathbf{M n}$ & $\mathbf{V}$ & $\mathbf{N b}$ & $\mathbf{T i}$ \\
\hline VL & Balance & 0.151 & 0.374 & 1.520 & 0.029 & 0.047 & 0.020 \\
VH & Balance & 0.156 & 0.370 & 1.601 & 0.041 & 0.047 & 0.020 \\
\hline
\end{tabular}


In order to avoid the test errors caused by core segregation and surface defects, the samples were selected at $1 / 4$ of the thickness direction of the plate and machined into a ø $10 \times 115 \mathrm{~mm}$ round rod for the standard hot tensile samples. The hot tensile tests were conducted on a Gleeble-3500 simulator in an argon atmosphere. Hot ductility was evaluated by measuring the area reduction of the tensile specimens strained to failure at various temperatures. Firstly, for studying the effect of $\mathrm{V}$ content on hot ductility, the samples of VL and VH steels were fully austenitized at $1250{ }^{\circ} \mathrm{C}$ with a heating rate of $5^{\circ} \mathrm{C} / \mathrm{s}$, held for $180 \mathrm{~s}$ and then cooled to various test temperatures in a range of $600 \sim 1200{ }^{\circ} \mathrm{C}$ at a cooling rate of $5^{\circ} \mathrm{C} / \mathrm{s}$. It was expected that the microalloying elements could be soluble at $1250{ }^{\circ} \mathrm{C}$. The samples were strained to failure at a strain rate of $1 \times 10^{-3} \mathrm{~s}^{-1}$ after holding for $60 \mathrm{~s}$ at the various testing temperatures and finally cooled to ambient temperature. In addition, to investigate the influence of strain rate on the hot ductility of the V-microalloyed steels, VL steel was deformed at the strain rate of $10 \mathrm{~s}^{-1}$ with same test procedures. The heat treatment procedure is provided in Figure 1.

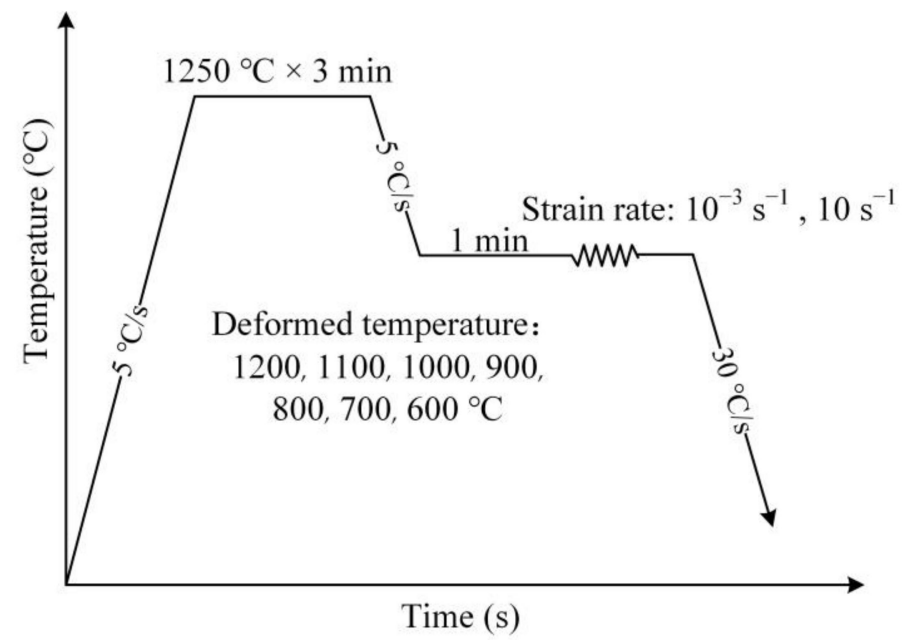

Figure 1. The experimental procedures.

After the thermal simulation experiments, the tensile properties of samples at different strain rates and tensile temperatures were obtained according to the stress-strain curve during the tensile process. An ultrasonic instrument was used to clean up the tensile fracture in an alcohol solution for removing the oxide layer on the surface of the fracture. A Nova 400 Nano field emission scanning electron microscope (FE-SEM) (FEI, Hillsboro, OR, USA) and an XTL-5000 stereo microscope (SM) were used to observe the morphology of the tensile fracture. Image-Pro Plus software (Media Cybernetics, MD, USA) was used to measure the fracture radius $\left(R_{2}\right)$ and original radius $\left(R_{1}\right)$ of each sample, and the equation $\delta=1-\mathrm{R}_{2}{ }^{2} / \mathrm{R}_{1}{ }^{2}$ was used to calculate the reduction in cross-section area, which would indicate the hot ductility. The larger the value of $\delta$, the better the hot ductility. Then, the microstructure just near to the fracture surface was observed using a Zeiss optical microscope (OM, Zeiss, Jena, Germany) at room temperature, and the Vickers hardness of the sample was measured using a HV-1000 A (Wowei Technology, Beijing, China) microhardness tester with a load of $0.05 \mathrm{kgf}$ and a loading time of $10 \mathrm{~s}$. The average value of 5 repetitions in each area and for at least 3 areas was calculated for each sample to ensure the accuracy of the data. Finally, the distribution and composition of carbides were examined by a PHILIPS CM12 transmission electron microscope (TEM) (Philips, Ann Arbor, USA) with an energy dispersive spectrometer (EDS). 


\section{Results and Discussion}

\subsection{Effect of Strain Rate on Hot Ductility}

Figure 2 provides the typical fracture morphology of VL steel after hot tensile tests at different temperatures and at strain rates of $10^{-3} \mathrm{~s}^{-1}$ and $10 \mathrm{~s}^{-1}$.

(a)

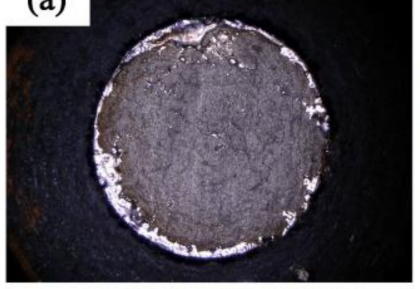

(d)

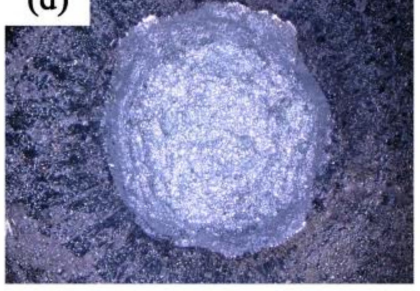

(b)

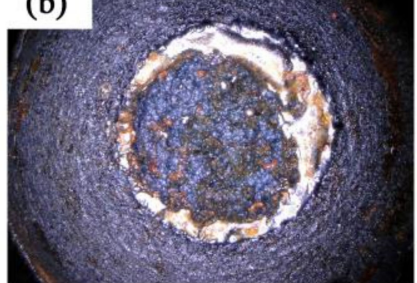

(e)

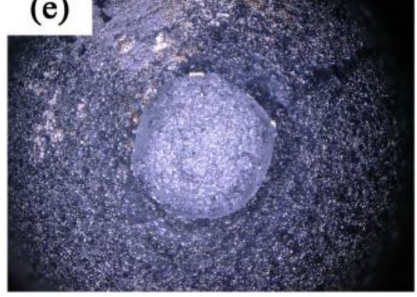

(c)
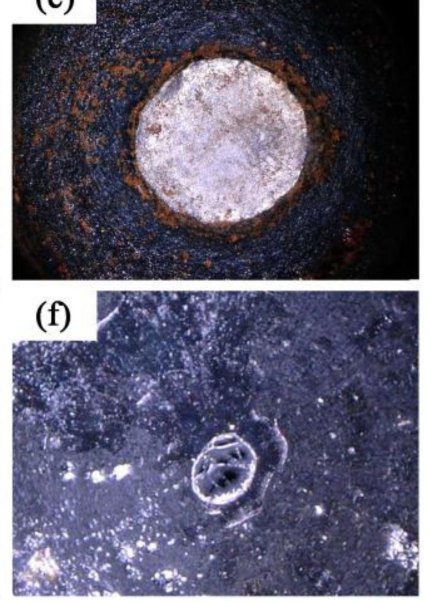

Figure 2. The typical fracture morphology of VL steel after hot tensile tests at different temperatures and strain rates: (a) $10^{-3} \mathrm{~s}^{-1}, 600{ }^{\circ} \mathrm{C}$; (b) $10^{-3} \mathrm{~s}^{-1}, 900{ }^{\circ} \mathrm{C}$; (c) $10^{-3} \mathrm{~s}^{-1}, 1200{ }^{\circ} \mathrm{C}$; (d) $10 \mathrm{~s}^{-1}, 600^{\circ} \mathrm{C}$; (e) $10 \mathrm{~s}^{-1}, 900{ }^{\circ} \mathrm{C}$; (f) $10 \mathrm{~s}^{-1}, 1200{ }^{\circ} \mathrm{C}$.

According to the fracture radius $\left(R_{2}\right)$ and original radius $\left(R_{1}\right)$ of each sample, the area reduction could be calculated. Based on the area reduction at different temperatures and strain rates, the hot ductility curves of VL steel were obtained and are shown in Figure 3. It is obvious that the hot ductility curve at a low strain rate $\left(10^{-3} \mathrm{~s}^{-1}\right)$ contains two ductility troughs located in the temperature ranges of $600 \sim 800{ }^{\circ} \mathrm{C}$ and $1100 \sim 1200{ }^{\circ} \mathrm{C}$, whereas it does not show the ductility trough when samples were fractured at a high strain rate $\left(10 \mathrm{~s}^{-1}\right)$, and it simply increases with the increase in fracture temperature.

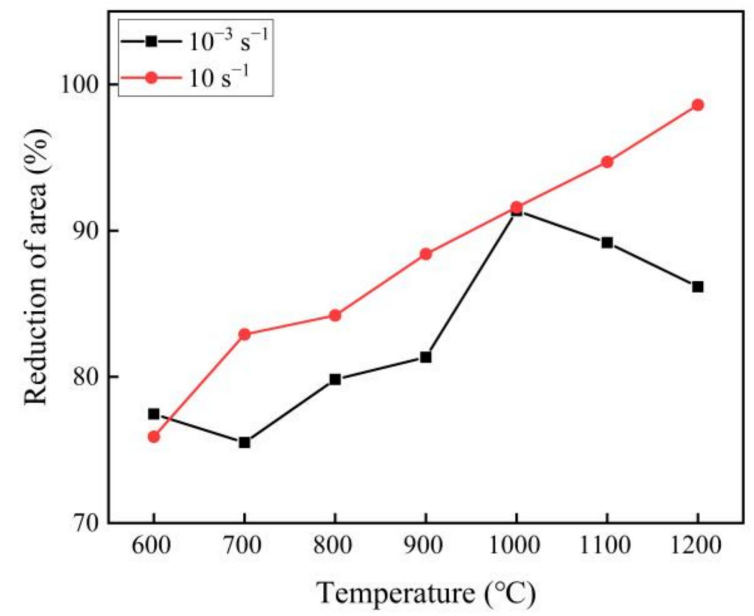

Figure 3. The curves of area reduction versus temperature of VL steel at different strain rates.

Figure 4 presents the microstructures observed by OM showing the cross-sectional area beneath the fracture surfaces of VL steel tested at different temperatures with a strain rate of $10^{-3} \mathrm{~s}^{-1}$. Figure 4 shows that at the strain rate of $10^{-3} \mathrm{~s}^{-1}$, the microstructure at room temperature mainly contained ferrite and pearlite in the $600^{\circ} \mathrm{C}$ fractured $(600$-fractured) sample, whereas there were ferrite and martensite in the 700-fractured sample and almost only martensite in samples fractured at $800{ }^{\circ} \mathrm{C}$ or above. It should be noted that ferrite and 
pearlite in the 600- and 700-fractured samples could only be formed before and/or during hot tensile testing because the sample was cooled to room temperature at a rate of $30^{\circ} \mathrm{C} / \mathrm{s}$ after samples were fractured.

(a)

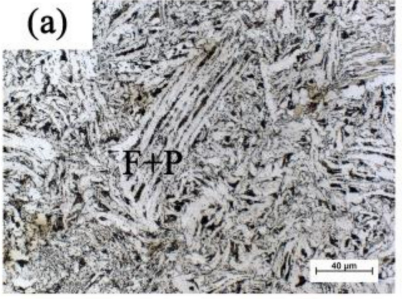

(d)

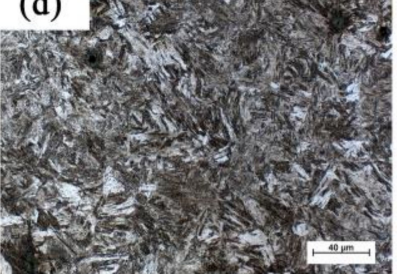

(b)

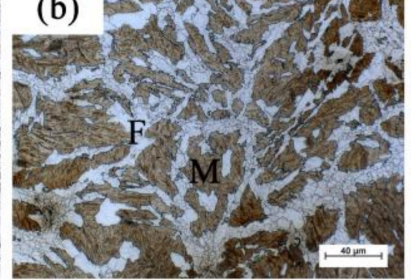

(e)

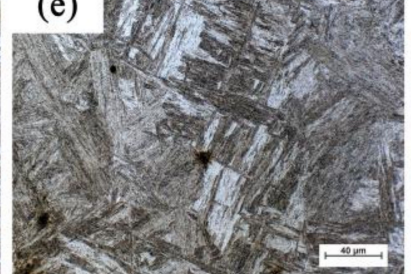

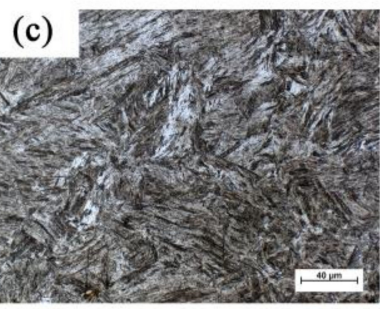

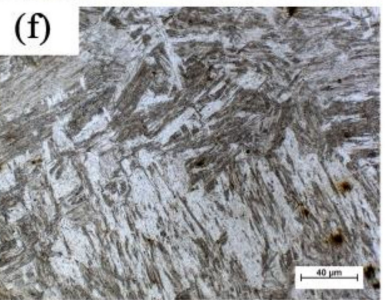

Figure 4. Microstructure of VL steel fractured at $600 \sim 1200^{\circ} \mathrm{C}$ with a strain rate of $10^{-3} \mathrm{~s}^{-1}$ : (a) $600{ }^{\circ} \mathrm{C}$; (b) $700{ }^{\circ} \mathrm{C}$; (c) $800{ }^{\circ} \mathrm{C}$; (d) $900{ }^{\circ} \mathrm{C}$; (e) $1000{ }^{\circ} \mathrm{C}$; (f) $1200{ }^{\circ} \mathrm{C}$.

Moreover, Figure 5 provides the microstructures of near fracture surfaces of samples tested at a strain rate of $10 \mathrm{~s}^{-1}$.
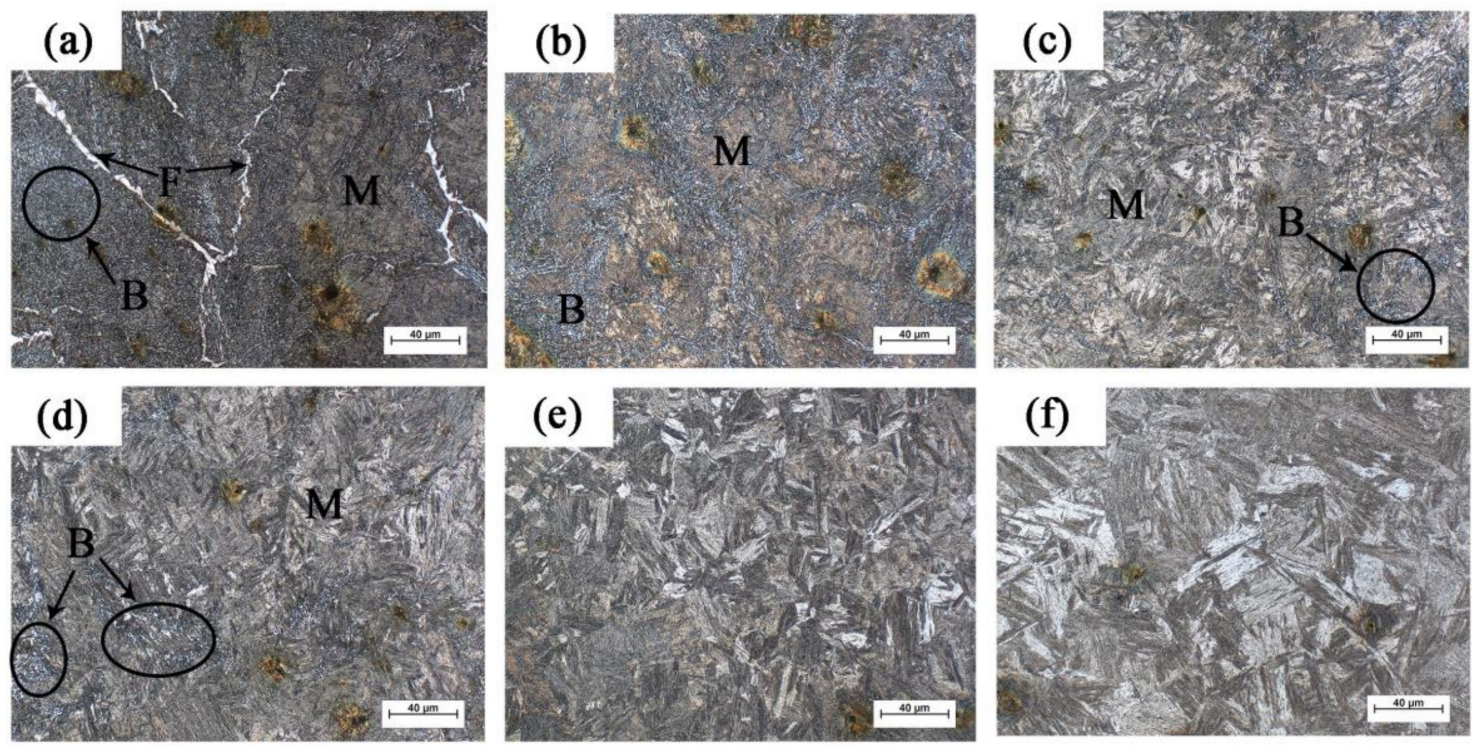

Figure 5. Microstructure of VL steel fractured at $600 \sim 1200{ }^{\circ} \mathrm{C}$ with a higher strain rate of $10 \mathrm{~s}^{-1}$ : (a) $600{ }^{\circ} \mathrm{C}$; (b) $700{ }^{\circ} \mathrm{C}$; (c) $800{ }^{\circ} \mathrm{C}$; (d) $900{ }^{\circ} \mathrm{C}$; (e) $1000{ }^{\circ} \mathrm{C}$; (f) $1200{ }^{\circ} \mathrm{C}$.

It was observed that the microstructure of the 600-fractured sample contained ferrite, bainite and martensite. Compared to the samples fractured at the low strain rate of $10^{-3} \mathrm{~s}^{-1}$, the amount of ferrite in the 600-fractured sample obviously decreased and the ferrite tended to precipitate along grain boundaries. This is because the fracture time of samples is shortened significantly due to the higher strain rate, leading to a shorter transformation time for ferrite transformation. Moreover, the distortion energy at the grain boundary is higher, so the formation of ferrite is easier to nucleate and grow at the grain boundary. When the hot tensile temperature was between $700 \sim 900{ }^{\circ} \mathrm{C}$, the microstructure was composed of bainite and martensite, whereas when the temperature rose to $1000{ }^{\circ} \mathrm{C}$ or above, ferrite disappeared and the microstructure only contained martensite. 
According to the hot ductility curves (Figure 3), the better hot ductility without the ductility trough was obtained at a higher strain rate $\left(10 \mathrm{~s}^{-1}\right)$, which is obviously different from the results obtained at a low strain rate $\left(10^{-3} \mathrm{~s}^{-1}\right)$. The hot ductility is mainly affected by intergranular ferrite and second particles. The intergranular ferrite has less time to grow up when it is hot fractured at a high strain rate. At low deformation temperatures $\left(600 \sim 800{ }^{\circ} \mathrm{C}\right)$, and with a high strain rate, the microstructure of the sample consisted of a large amount of austenite and very limited ferrite, resulting in a good deformation correspondence during the hot tensile process. It is easy to know that, under the premise of the same steel, a single phase in the final microstructure will result in a better hot plasticity during the tensile process than complex phases. Moreover, the second particles at the grain boundary have no sufficient time to precipitate at a fast strain rate. When the fractured temperature was higher $\left(>1000^{\circ} \mathrm{C}\right)$, the intergranular crack had less time to nucleate and grow up at a high strain rate, i.e., increasing strain rate could reduce the time for the propagation of voids and, therefore, postpone final fracture and improve the hot ductility. Wang et al. [13] reported that a higher strain rate is beneficial for grain refinement and for preventing the formation and propagation of hot cracking during the high temperature tensile process. This is in good agreement with the present result.

However, the sample needed more time to be fractured at low strain rate of $10^{-3} \mathrm{~s}^{-1}$. When the sample was deformed at low temperature, there was a longer time for ferrite transformation, so the austenite and ferrite coexisted in the final microstructure. In addition, Figure 6 shows the yield strength of austenite and ferrite and the percentage of yield strength difference between two phases against temperature, calculated by JMatPro software (Sente Software, Guildford, UK).

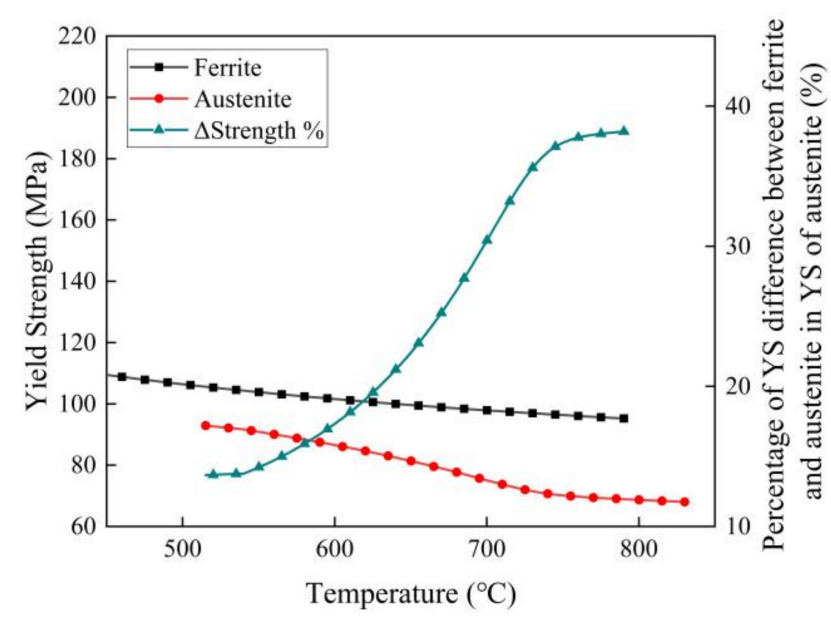

Figure 6. The yield strength of austenite and ferrite and strength difference of two phases versus temperature.

This indicates that the strength difference between austenite and ferrite increased with the increasing testing temperature. It is well known [14-17] that the poor deformation correspondence due to the existence of two different phases during the tensile process will easily lead to the occurrence of microcracks. Therefore, at the low strain rate, the ductility trough zone appears at the range of $600 \sim 800{ }^{\circ} \mathrm{C}$. At a higher temperature deformation of above $1000{ }^{\circ} \mathrm{C}$, longer tensile time leads to grain boundary melting [18]. Therefore, at a low strain rate, the hot ductility tends to deteriorate continuously with the increasing temperature when the deformation temperature is higher than $1000{ }^{\circ} \mathrm{C}$.

\subsection{Effect of V Content on Hot Ductility}

In order to study the effect of $\mathrm{V}$ content on the hot ductility trough, $\mathrm{VH}$ steel was hot fractured at the same testing temperature range of $600 \sim 1200{ }^{\circ} \mathrm{C}$ with a strain rate of $10^{-3} \mathrm{~s}^{-1}$. Figure 7 shows the typical fracture morphology of $\mathrm{VH}$ steel after being fractured. 


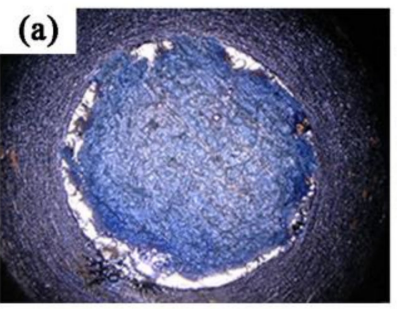

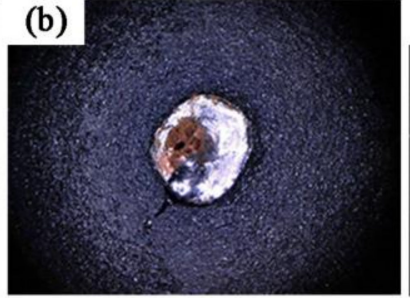

(c)

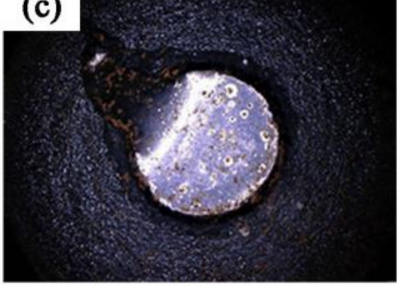

Figure 7. The fracture morphology of $\mathrm{VH}$ steel after hot tensile test at different temperatures: (a) $700{ }^{\circ} \mathrm{C}$, (b) $1000{ }^{\circ} \mathrm{C}$ and (c) $1200{ }^{\circ} \mathrm{C}$.

The curves of area reduction against temperature for $\mathrm{VH}$ steel were obtained based on fracture morphologies, and the hot ductility curves of two steels are provided in Figure 8. It can be observed that the two hot ductility curves showed a similar change trend with temperature. An obvious hot ductility trough was also observed in the VH steel in the temperature range of $600 \sim 900{ }^{\circ} \mathrm{C}$. Compared to the VL steel, the VH steel had a deeper ductility trough. In addition, when the tensile temperature was lower than $900{ }^{\circ} \mathrm{C}$, the hot ductility of VL steel was obviously better than that of VH steel, while it was only slightly worse than that of $\mathrm{VH}$ steel when the tensile temperature was higher than $1000{ }^{\circ} \mathrm{C}$. Besides, the lowest area reduction of $\mathrm{VL}$ and $\mathrm{VH}$ steels were 75.5 and $66.5 \%$ at the fracture temperature of $700{ }^{\circ} \mathrm{C}$ and the best ones were $91.3 \%$ and $93.9 \%$ at $1000{ }^{\circ} \mathrm{C}$, respectively.

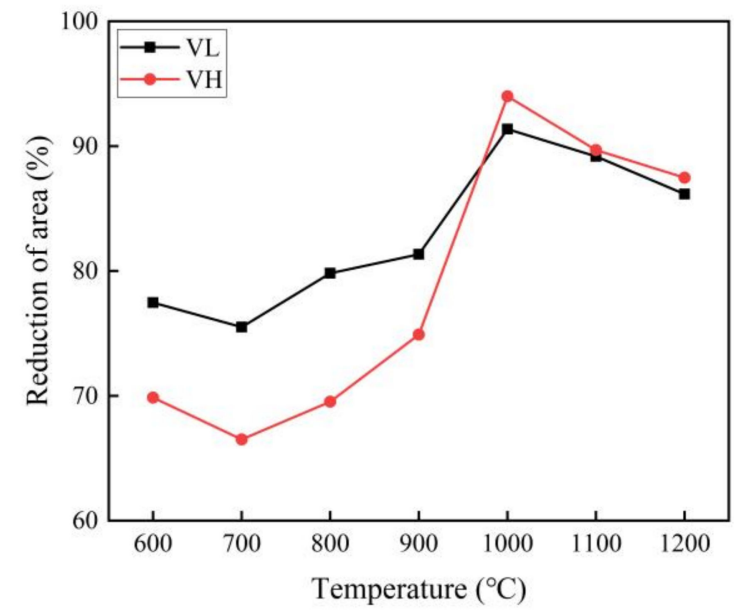

Figure 8. The curves of hot ductility versus temperature of VL and VH steels at a strain rate of $10^{-3} \mathrm{~s}^{-1}$.

Figure 9 shows the room temperature microstructure near the fracture surface of $\mathrm{VH}$ steel fractured at different temperatures with a strain rate of $10^{-3} \mathrm{~s}^{-1}$.

The 800-fractured sample contained martensite and began to appear with bainite (circled in Figure 9c). Compared with the microstructure in the 600-fractured sample of VL steel (Figure 4), it was found that there was not only ferrite and pearlite, but also martensite in the 600-fractured sample of VH steel. Here, it is noted that the crystal microstructure after major deformation should be different with the increase in $\mathrm{V}$ content because it is known that the precipitates containing $\mathrm{V}$ can retard the motion of dislocation and grain boundary. However, in the present study, one of the innovations is to clarify the effect of $\mathrm{V}$ content on hot ductility, therefore, the relationship between the major deformation mechanisms of hot ductility and the results of crystal structure analysis are not investigated at present but will be analyzed in the next work. 

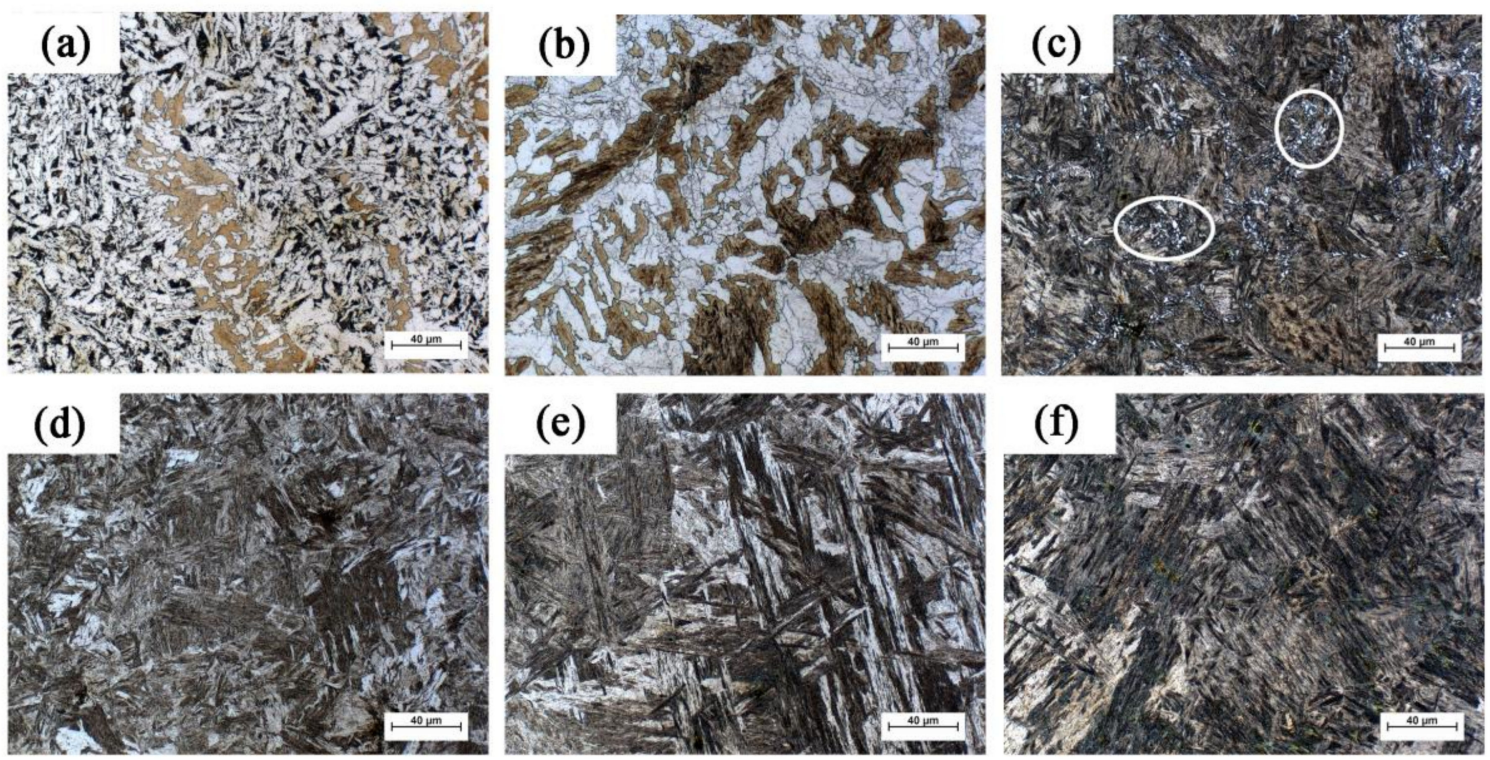

Figure 9. The microstructures near the fracture surface of $\mathrm{VH}$ steel fractured at $600 \sim 1200{ }^{\circ} \mathrm{C}$ with a strain rate of $10^{-3} \mathrm{~s}^{-1}$ : (a) $600{ }^{\circ} \mathrm{C}$; (b) $700{ }^{\circ} \mathrm{C}$; (c) $800{ }^{\circ} \mathrm{C}$; (d) $900{ }^{\circ} \mathrm{C}$; (e) $1000{ }^{\circ} \mathrm{C}$; (f) $1200{ }^{\circ} \mathrm{C}$.

For VL and VH steels fractured at $700{ }^{\circ} \mathrm{C}$ with the same strain rate of $10^{-3} \mathrm{~s}^{-1}$, there was more ferrite in the microstructure than in the 600-fractured sample. The diffusion rate of carbon was faster because of the higher temperature, so the size and amount of ferrite in the 700-fractured samples were obviously larger than those of the 600-fractured samples in both the steels. In addition, it was observed that the ferrite in VL steel was distributed along the original austenite grain boundary and was connected to form a dense ferrite network (Figure $4 \mathrm{~b}$ ). Ferrite preferentially nucleates at the grain boundary, and the ferrite transformation is accompanied with the ejection of carbon from ferrite into austenite, which restricts the growth of grain boundary ferrite into austenite so that the ferrite grows along the grain boundaries. However, this phenomenon was not obvious in the 700-fractured sample of VH steel. Figure 10a shows an example of the typical precipitates of VH steel fractured at $700{ }^{\circ} \mathrm{C}$ observed by the TEM, and the inset figure provides the corresponding EDS result of a particle, indicating that the precipitates were the complex carbide precipitate of $\mathrm{Nb}, \mathrm{V}$ and Ti.
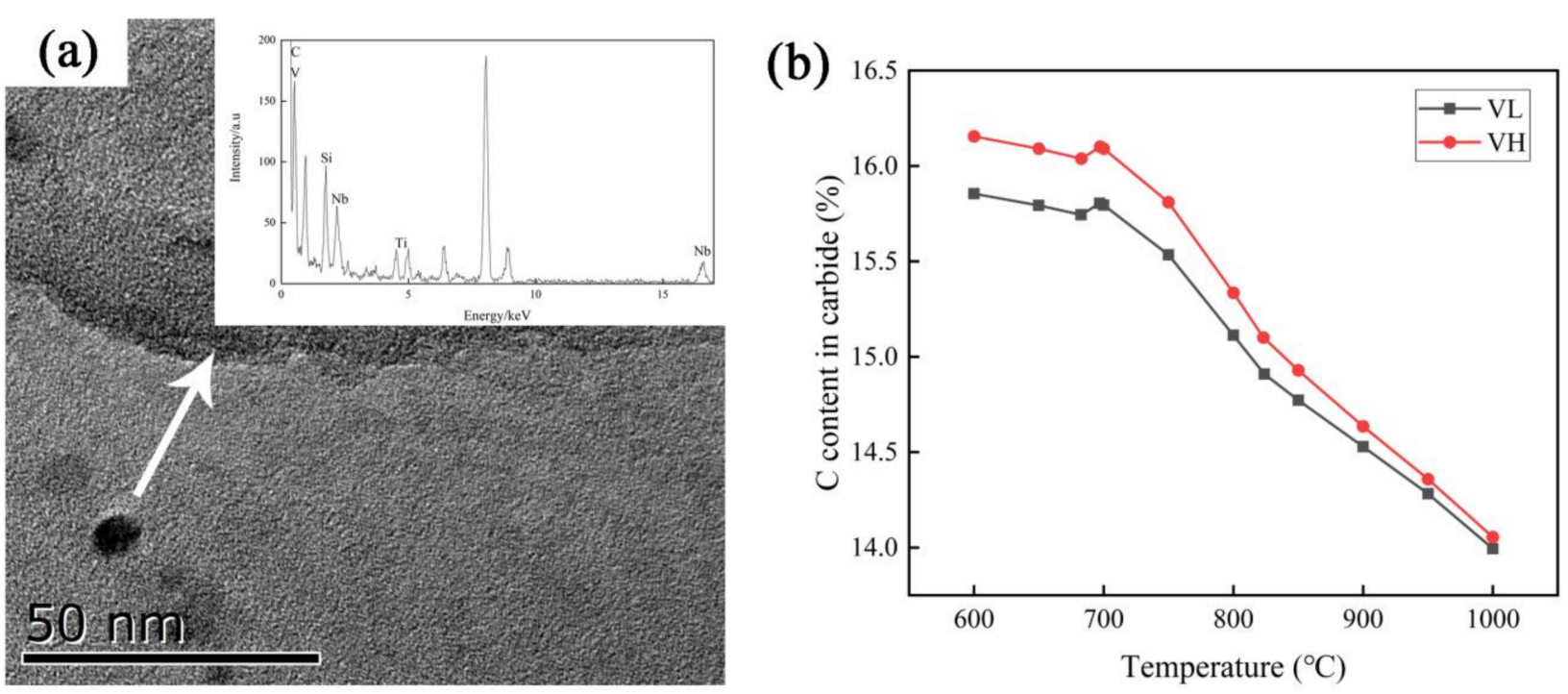

Figure 10. (a) TEM microstructure with the EDS result of 700-fractured sample of VH steel; (b) the curves of the carbon content in carbide versus temperature in two steels. 
In addition, the TEM result shows that the particles mostly precipitated at grain boundary. The carbide precipitates containing $\mathrm{V}$ in the undercooled austenite are beneficial for the heterogeneous nucleation [19], which makes the formation of ferrite within the austenite grain possible. Compared with VL steel, VH steel contains more precipitates due to the higher amount of $\mathrm{V}$, leading to more ferrite in the microstructure [20]. Moreover, Figure $10 \mathrm{~b}$ plots the curves of $\mathrm{C}$ content in carbide against temperature of VL and VH steels calculated by JMatPro software (Sente Software, Guildford, UK). It can be seen that the content of $\mathrm{C}$ in the carbide of $\mathrm{VH}$ steels was higher than that of VL steel, but the total $\mathrm{C}$ content of the two steels was equal; thus, it is inferred that the content of $\mathrm{C}$ in the undercooled austenite of VH steel is lower than that of VL steel, meaning that, at the same fractured temperature, the undercooled austenite in $\mathrm{VH}$ steel is more unstable, leading to an easy ferrite transformation. Therefore, $\mathrm{VH}$ steel has a larger volume fraction of ferrite than that of VL steel. Increased ferrite will lead to a worse deformation coordination, as explained in Section 3.1, which results in a deeper ductility trough in VH steel.

On the other hand, the carbide precipitates could also provoke a loss of the hot ductility of steels by themselves, as reported by many published works [21-26]. The precipitates at grain boundaries reduce the binding force of grain boundaries, retard the onset of dynamic recrystallization and cause stress concentration, thus promoting intergranular failure and reducing hot ductility.

Figure 11a,b provides the NrT curve (nucleation rate-temperature curve) and PTT curve (precipitation-time-temperature curve) of $(\mathrm{Nb}, \mathrm{V}, \mathrm{Ti}) \mathrm{C}$ in austenite in the VL and VH steels, respectively, calculated by the method published in references [27-32]. Figure 11c provides the percentage of $(\mathrm{Nb}, \mathrm{V}, \mathrm{Ti}) \mathrm{C}$ precipitated in austenite calculated by the same method.
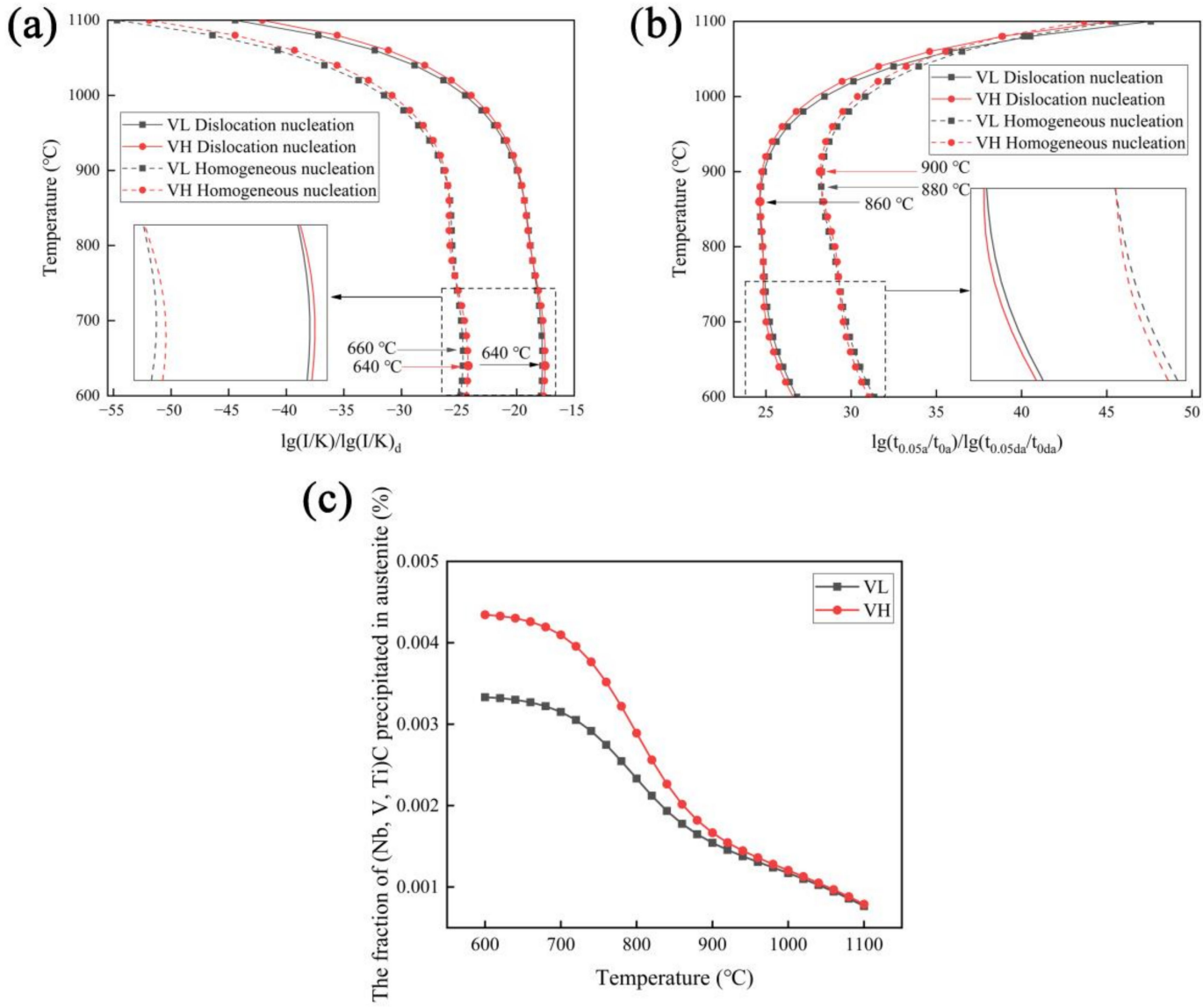

Figure 11. (a) The NrT curve (nucleation rate-temperature curve); (b) the PTT curve (precipitationtime-temperature curve); (c) the curves of the fraction of $(\mathrm{Nb}, \mathrm{V}, \mathrm{Ti}) \mathrm{C}$ precipitated in austenite versus temperature. 
It can be observed from the magnified figure in Figure 11a that the maximum nucleation rate temperature of the two steels is about $640{ }^{\circ} \mathrm{C}$, regardless of whether it is homogeneous nucleation or dislocation line nucleation. Increasing the $\mathrm{V}$ content causes the NrT curve to shift to the right, thereby increasing the nucleation rate of precipitates. In addition, from the magnified figure in Figure 11b, it can be observed that increasing the V content causes the PTT curve to shift to the left, indicating that the increase in the amount of $\mathrm{V}$ shortens the precipitation time. The results obtained from Figure 11a,b mean that more $\mathrm{V}$ will lead to more precipitates. Figure 11c indicates that the precipitates in $\mathrm{VH}$ steel are greater than that in VL steel, which is consistent with the analysis result from Figure 11a,b. More precipitates lead to more loss in hot ductility. This is the second reason why the deeper ductility trough occurs in VH steel.

In addition, Figure 12 provides the relationship between the chemical formula coefficients of $\left(\mathrm{Nb}_{\mathrm{x}}, \mathrm{V}_{\mathrm{y}}, \mathrm{Ti}_{\mathrm{z}}\right) \mathrm{C}$ precipitated in ferrite in both steels.

(a)

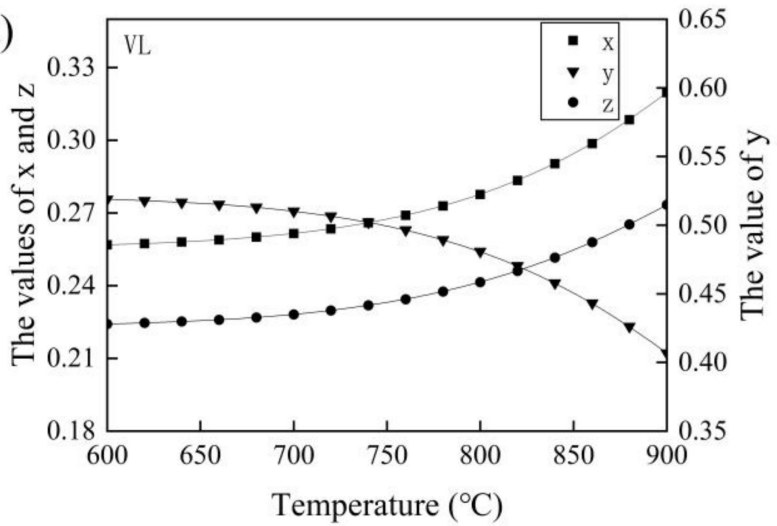

(b)

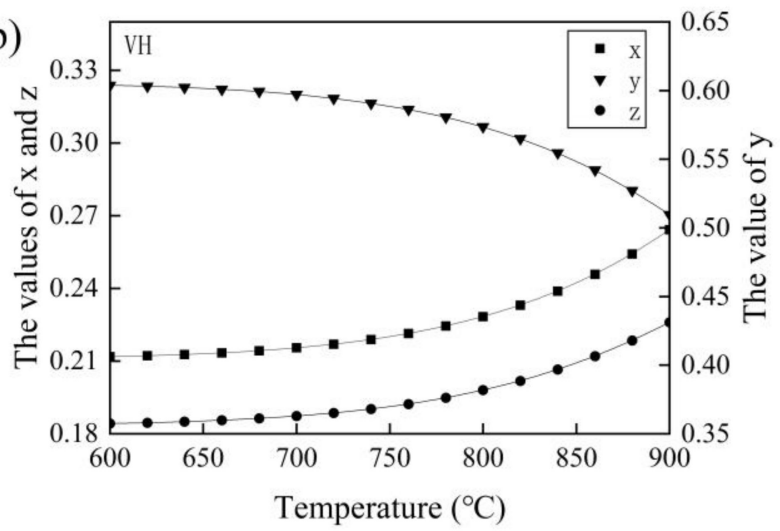

Figure 12. The relationship between the chemical formula coefficients of $\left(\mathrm{Nb}_{\mathrm{x}}, \mathrm{V}_{\mathrm{y}}, \mathrm{Ti}_{\mathrm{z}}\right) \mathrm{C}$ precipitated in ferrite and temperature in: (a) VL steel; and (b) VH steel.

It can be clearly observed that the chemical formula coefficients of $\mathrm{X}$ and $\mathrm{Z}$ of $\mathrm{Nb}$ and $\mathrm{Ti}$ in the carbide in VL steel are larger than those of VH steel at the same temperature, and the chemical formulas of the precipitates in $\mathrm{VL}$ and $\mathrm{VH}$ steels at $700{ }^{\circ} \mathrm{C}$ are $\left(\mathrm{Nb}_{0.26}, \mathrm{~V}_{0.51}, \mathrm{Ti}_{0.23}\right)$ $\mathrm{C}$ and $\left(\mathrm{Nb}_{0.21}, \mathrm{~V}_{0.60}, \mathrm{Ti}_{0.19}\right) \mathrm{C}$, respectively. As the lattice constants of $\mathrm{NbC}$ and $\mathrm{TiC}$ are larger than those of VC [27], the lattice constants of composite precipitates $\left(\mathrm{Nb}_{\mathrm{x}}, \mathrm{V}_{\mathrm{y}}, \mathrm{Ti}_{\mathrm{z}}\right) \mathrm{C}$ in the two steels for the 700-fractured samples were calculated to be $0.4314 \mathrm{~nm}$ and $0.4296 \mathrm{~nm}$, respectively. Figure 13 shows an example of high-resolution and diffraction pattern results of VH steel fractured at $700{ }^{\circ} \mathrm{C}$. The calculated lattice constant was $0.4300 \mathrm{~nm}$, which is consistent with the theoretical calculation result $(0.4296 \mathrm{~nm})$. As Mohamed reported [5], at the same level of precipitates, the coarser carbides are less effective in reducing hot ductility. In the present study, the size of the carbides in VL steel was larger than that in VH steel; therefore, the hot ductility trough in VH steel was deeper than that in VL steel. This is another reason for the deeper hot ductility in $\mathrm{VH}$ steel.

When the fracture temperature was increased to $1000{ }^{\circ} \mathrm{C}$, the area reductions of the two steels were improved (Figure 8), which may contribute to dynamic recovery and recrystallization [33]. Fine grain could lead the large cracks to branch into several small cracks, thus delaying the propagation of large cracks and preventing the occurrence of fracture $[11,34,35]$. In addition, Figure 14 shows the curves of the solution amount of $\mathrm{V}$ in austenite against temperature in two steels. It is seen that the content of $\mathrm{V}$ in solid solution in VH steel was higher than that in VL steel. More V in the solid solution in austenite inhibits the growth of parental austenite grain by solute drag effect [36], which results in finer grains. Finer grains could be easily rotated to a lower Taylor factor, which is considered to be "softer", to further inhibit cracking during the hot tensile process [37]. 
Therefore, when the fracture temperature is higher than $1000{ }^{\circ} \mathrm{C}$, the hot ductility of $\mathrm{VH}$ steel is slightly better than that of VL steel.
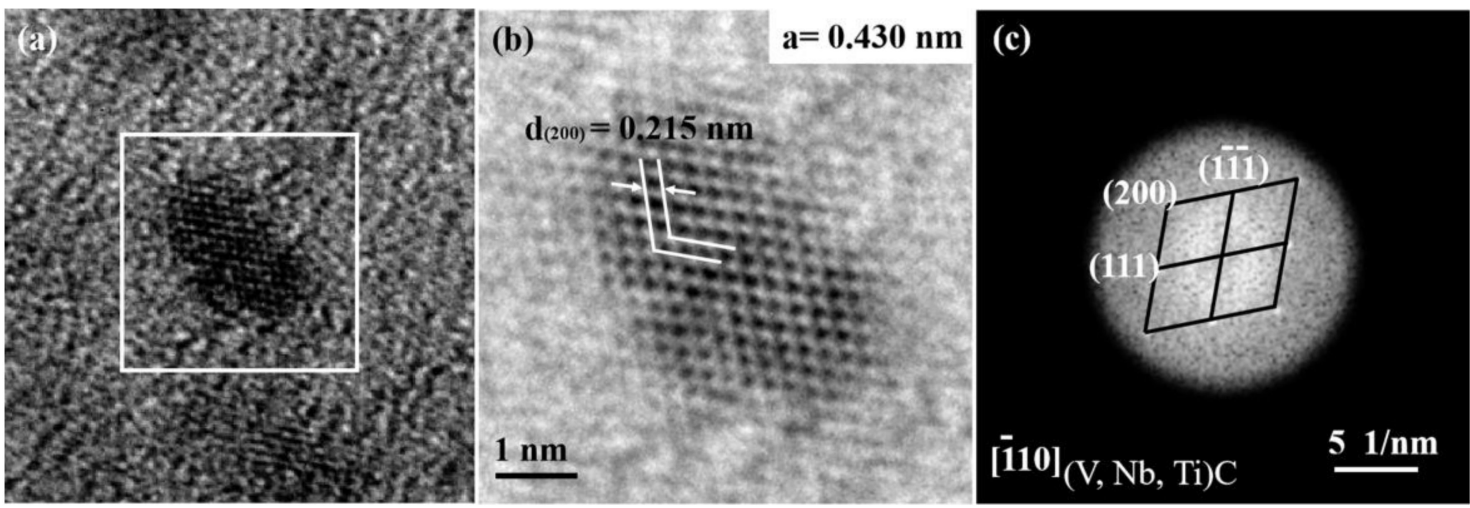

Figure 13. (a) TEM image of precipitates in $\mathrm{VH}$ steel fractured at $700{ }^{\circ} \mathrm{C} ;(\mathbf{b})$ crystal plane spacing and lattice constant; (c) the diffraction spot after the Fourier transform.

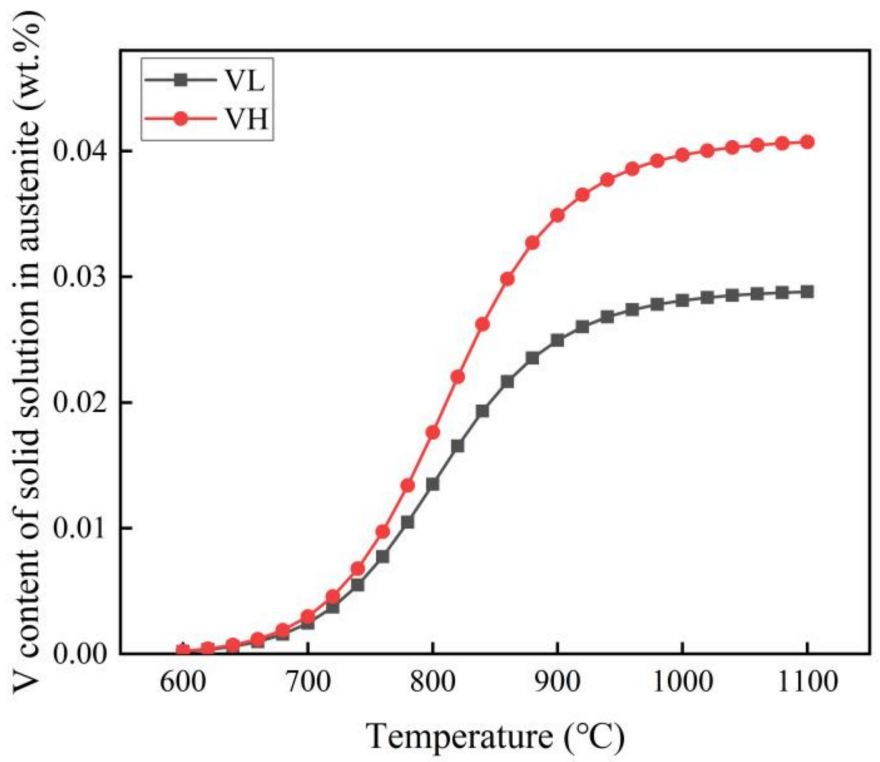

Figure 14. Relationship between temperature and V content of solid solution in austenite of VL and VH steels.

\section{Conclusions}

The hot ductility of two low-carbon microalloyed steels was investigated using hot tensile tests performed up to fracture at temperatures ranging from 600 to $1200{ }^{\circ} \mathrm{C}$ and with two different strain rates of $10^{-3} \mathrm{~s}^{-1}$ and $10 \mathrm{~s}^{-1}$. The following conclusions can be drawn:

(1) The hot ductility trough occurs at a low strain rate because of the sufficient time for ferrite transformation and the growth of the second particles, yet it disappears at a high strain rate.

(2) With the increase in strain rate, the hot ductility is improved at the higher fractured temperatures of 700 to $1200{ }^{\circ} \mathrm{C}$, but it deteriorates at the lowest fractured temperature of $600{ }^{\circ} \mathrm{C}$.

(3) In the low fractured temperature range $\left(600 \sim 900^{\circ} \mathrm{C}\right)$, the larger amount of precipitates and increased ferrite transformation both result in poorer hot ductility with the increase in the $\mathrm{V}$ content, whereas the hot ductility is improved at the high fractured temperature range of $1000 \sim 1200{ }^{\circ} \mathrm{C}$ due to grain refinement strengthening. 


\begin{abstract}
Author Contributions: J.T. conceived and designed the experiments; S.S. conducted experiments and analyzed the data; J.X. conducted experiments; L.F. conducted experiments and analyzed the data; Y.Y. conducted experiments; Q.Y. conducted experiments; X.G. conducted experiments; G.X. conceived the experiments. All authors have read and agreed to the published version of the manuscript.

Funding: The authors gratefully acknowledge the financial support from National Natural Science Foundation of China (No. 52104381), Natural Science Foundation of Hubei (No. 2021CFB127), the Major Project of Science and Technology of Guangxi (AA 19254009), the Key Project of Science and Technology of Liuzhou Municipal Government (2019AC10602), the Open Fund of Hubei Provincial Key Laboratory for New Processes of Ironmaking and Steelmaking (KF-20-4).
\end{abstract}

Institutional Review Board Statement: No applicable.

Informed Consent Statement: No applicable.

Data Availability Statement: No applicable.

Conflicts of Interest: The authors declare no conflict of interest. The founding sponsors had no role in the design of the study; in the collection, analyses or interpretation of data; in the writing of the manuscript, or in the decision to publish the results.

\title{
References
}

1. Fedosov, A.V.; Skrebtsov, A.M.; Pashchuk, D.V. Formation of transverse surface cracks during peritectic steel continuous casting. Metallurgist 2018, 62, 39-48. [CrossRef]

2. Li, Y.F.; Wen, G.H.; Tang, P.; Li, J.Q.; Xiang, C.L. Effect of slab subsurface microstructure evolution on transverse cracking of microalloyed steel during continuous casting. J. Iron Steel Res. Int. 2014, 21, 737-744. [CrossRef]

3. Ma, F.J.; Wen, G.H.; Tang, P.; Yu, X.; Li, J.Y.; Xu, G.D.; Mei, F. Causes of transverse corner cracks in microalloyed steel in vertical bending continuous slab casters. Ironmak Steelmak 2010, 37, 73-79. [CrossRef]

4. Mintz, B.; Abushosha, R. Influence of vanadium on hot ductility of steel. Ironmak Steelmak 1993, 20, 445-452.

5. Mohamed, Z. Hot ductility behavior of vanadium containing steels. Mater. Sci. Eng. A 2002, 326, 255-260. [CrossRef]

6. Lee, C.H.; Park, J.Y.; Chung, J.H.; Park, D.B.; Jang, J.Y.; Huh, S.; Kim, S.J.; Kang, J.Y.; Moon, J.; Lee, T.H. Hot ductility of medium carbon steel with vanadium. Mater. Sci. Eng. A 2016, 651, 192-197. [CrossRef]

7. Sun, Y.H.; Zeng, Y.N.; Cai, K.K. Hot ductility of Ti-V bearing microalloyed steel in continuous casting. J. Iron Steel Res. Int. 2014, 21, 451-458. [CrossRef]

8. Salas-Reyes, A.E.; Mejia, I.; Bedolla-Jacuinde, A.; Boulaajaj, A.; Calvo, J.; Cabrera, J.M. Hot ductility behavior of high-Mn austenitic Fe-22Mn-1.5Al-1.5Si-0.45C TWIP steels microalloyed with Ti and V. Mater. Sci. Eng. A 2014, 611, 77-89. [CrossRef]

9. Irvine, K.J.; Pickering, F.B. Grain-refined C-Mn steels. J. Iron Steel Inst. 1967, 205, 161.

10. Zheng, Y.X.; Shen, W.; Zhu, L.G.; Guo, Z.H.; Wang, Q.; Feng, J.; Li, Y.L.; Cao, R.F.; Wu, J.Y. Effects of composition and strain rate on hot ductility of Cr-Mo-alloy steel in the two-phase region. High Temp. Mater. Processes 2021, 40, 228-240. [CrossRef]

11. Wang, Z.H.; Meng, Q.; Qu, M.G.; Zhou, Z.A.; Wang, B.; Fu, W.T. Effect of strain rate on hot ductility behavior of a high nitrogen Cr-Mn austenitic steel. Metall. Mater. Trans. A 2016, 47, 1-12. [CrossRef]

12. Crowther, D.N.; Mohamed, Z.; Mintz, B. Influence of micro-alloying additions on the hot ductility of steels heated directly to the test temperature. Trans. Iron Steel Inst. Jpn. 2006, 27, 366-375. [CrossRef]

13. Großeiber, S.; Ilie, S.; Poletti, C.; Harrer, B.; Degischer, H.P. Influence of strain rate on hot ductility of a V-microalloyed steel slab. Steel Res. Int. 2012, 83, 445-455. [CrossRef]

14. Lu, C.Z.; Li, J.Y.; Gao, Z.J.; Zhang, T.R.; Chen, Y.L.; Wang, Y.D. Thermoplasticity and microstructure evolution of duplex stainless steel 0Cr25Ni7Mo4N subjected to high-temperature tensile deformation. Mater. Rev. 2018, 32, 1639-1644.

15. Lekganyane, K.M.; Mostert, R.J.; Siyasiya, C.W.; Banks, K.M. Irreversible loss of hot ductility following simulated primary cooling of a C-Mn steel to temperatures above the ferrite transformation temperature. Mater. Sci. Eng. A 2021, 810, 141007. [CrossRef]

16. Seo, C.S.; Son, K.S.; Lee, S.K.; Kim, I.; Lee, T.J.; Yim, C.; Kim, D. Variation of hot ductility behavior in as-cast and remelted steel slab. Met. Mater. Int. 2008, 14, 559-563. [CrossRef]

17. Zheng, Y.X.; Wang, F.M.; Li, C.R.; Cheng, J.; Li, Y.L. Effect of compound addition of Nb-B on hot ductility of Cr-Mo alloy steel. Mater. Sci. Eng. A 2018, 715, 194-204. [CrossRef]

18. Li, J.Y.; Cheng, G.G. Hot ductility of Cr15Mn7Ni4N austenitic stainless steel slab. J. Mater. Res. Technol. 2020, 9, 52-58. [CrossRef]

19. Wang, W.; Fu, L.M. Effect of the inclusion/precipitation size on the intraganular ferrite nucleation. Acta Metall. Sin. 2008, 44, 723-728.

20. Hurtado-Delgado, E.; Morales, R.D. Hot ductility and fracture mechanisms of a C-Mn-Nb-Al steel. Metall. Mater. Trans. B 2001, 32, 919-927. [CrossRef]

21. Lara, V.H.; Fuentes, L.G.; Alvarado, O.C.; Rodriguez, A.S.; Sanchez, E.G. Hot ductility of the 17-4 PH stainless steels. J. Mater. Eng. Perform. 2016, 25, 1041-1046. [CrossRef] 
22. Furumai, K.; Wang, X.; Zurob, H.; Phillion, A. Evaluating the effect of the competition between NbC precipitation and grain size evolution on the hot ductility of $\mathrm{Nb}$ containing steels. ISIJ Int. 2019, 59, 1064-1071. [CrossRef]

23. Wang, Z.H.; Yong, W.; Wang, C.M. Grain size effect on the hot ductility of high-nitrogen austenitic stainless steel in the presence of precipitates. Materials 2018, 11, 1026. [CrossRef]

24. Mintz, B.; Kang, S.; Qaban, A. The influence of grain size and precipitation and a boron addition on the hot ductility of a high Al, V containing TWIP steels. Mater. Sci. Technol. 2021, 37, 1035-1046. [CrossRef]

25. Fares, M.L.; Darsouni, A.; Coze, J.L. Comparing the hot ductility behaviour of low-carbon microalloyed Nb-V-Ti steels during two thermal cycling routes: Solutionizing and precipitation treatments. Steel Res. Int. 2015, 86, 1090-1103. [CrossRef]

26. Vedani, M.; Dellasega, D.; Mannuccii, A. Characterization of grain-boundary precipitates after hot-ductility tests of microalloyed steels. ISIJ Int. 2009, 49, 446-452. [CrossRef]

27. Yong, Q.L. Secondary Phases in Steels; Metallurgical Industry Press: Beijing, China, 2016; pp. 269-306.

28. Zhang, K.; Sun, X.J.; Li, Z.D.; Xu, K.; Jia, T.; Zhu, Z.H.; Ye, X.Y.; Kang, J.Y.; Yong, Q.L. Effect of Ti/V ratio on thermodynamics and kinetics of MC in $\gamma / \alpha$ matrices of Ti-V microalloyed steels. J. Iron Steel Res. Int. 2021, 28, 1019-1029. [CrossRef]

29. Pang, Q.H.; Guo, J.; Li, W.J.; Tang, D.; Zhao, Z.Z.; Qi, H.; Wang, J.J. Complex precipitation mechanism of Ti-Nb-V microalloyed bainitic base high strength steel. J. Wuhan Univ. Technol. 2019, 34, 1444-1450. [CrossRef]

30. Fang, F.; Yong, Q.L.; Yang, C.F.; Su, H. A model for precipitation kinetics in vanadium microalloyed steel. J. Iron Steel Res. Int. 2010, 17, 36-42. [CrossRef]

31. Hu, B.H.; Cai, Q.W.; Wu, H.B. Kinetics of precipitation behavior of second phase particles in ferritic Ti-Mo microalloyed steel. J. Iron Steel Res. Int. 2013, 20, 69-77. [CrossRef]

32. Medina, S.F. Determination of precipitation-time-temperature (PTT) diagrams for Nb, Ti or V micro-alloyed steels. J. Mater. Sci 1997, 32, 1487-1492. [CrossRef]

33. Chen, B.H.; Yu, H. Hot ductility behavior of V-N and V-Nb microalloyed steels. Int. J. Miner. Metall. Mater. 2012, 19, 525-529. [CrossRef]

34. Liu, Y.; Sun, Y.H.; Wu, H.T. Effects of chromium on the microstructure and hot ductility of Nb-microalloyed steel. Int. J. Miner. Metall. Mater. 2021, 28, 1011-1021. [CrossRef]

35. Matveev, M.A.; Kolbasnikov, N.G.; Kononov, A.A. Causes of high temperature ductility trough of microalloyed steels. Trans. Indian Inst. Met. 2017, 70, 2193-2204. [CrossRef]

36. Kim, K.S.; Du, L.X.; Choe, H.S.; Lee, T.H.; Lee, G.C. Influence of vanadium content on hot deformation behavior of low-carbon boron microalloyed steel. Acta Metall. Sin. 2020, 33, 705-715. [CrossRef]

37. Wang, Z.H.; Sun, S.H.; Wang, B.; Shi, Z.P.; Fu, W.T. Importance and role of grain size in free surface cracking prediction of heavy forgings. Mater. Sci. Eng. A 2015, 625, 321-330. [CrossRef] 